\title{
Absence of the Arteria Profunda Femoris
}

\author{
Ausencia de la Arteria Femoral Profunda \\ *Otag, I.; * Çimen, M.; *** Solak, O.; **** Otag, A.; **** Çimen, F. G. \& **Kosar, M. I.
}

OTAG, I.; ÇIMEN, M.; SOLAK, O.; OTAG, A.; ÇIMEN, F. G. \& KOSAR, M. I. Absence of the arteria profunda femoris. Int. J. Morphol., 30(2):428-431, 2012.

SUMMARY: At arteria femoralis, arteria profunda femoris is the main branch feeding the thigh. After iliofemoral embryological evolution many variations can be seen in this vessel. The absence of a. profunda femoris is one of the rare seen variation among these variations. Knowing the anatomy and variations of a. profunda femoris well, is important in low extremity ischemia, vessel surgery and angiography applications. In this study, 1036 films belonging to low extremity found in the Radiology department of School of Medicine of Cumhuriyet University were examined as retrospective. Among these films at four of them of male cases, absence of a. profunda femoris was detected. In cases at ages of 32, 37, 47 and 53 respectively, in the first and second case at the right low extremity there was no a. profunda femoris and at the left low extremity it was seen that a. circumflexus femoris medialis and a. circumflexus femoris lateralis emerged from a. profunda femoris. In the third case it was detected that at left low extremity a. profunda femoris did not exist, and at right low extremity a. circumflexus femoris lateralis emerged from a. profunda femoris, and a. circumflexus femoris medialis emerged from a. femoralis. In the fourth case at left low extremity there was no a. profunda femoris and at right low extremity it was seen that at a. profunda femoris and a. femoralis were in unsteady course. The absence of a. profunda femoris had $0,4 \%$. The results were discussed by comparing with literature data.

KEY WORDS: Arteria profunda femoris; Arteria femoralis; Variation; Angiography.

\section{INTRODUCTION}

Arteria profunda femoris (apf), is a thick limb that separates from the rear outer surface of a. femoralis $2-5 \mathrm{~cm}$ below lig. inguinale. It first reaches below lateral to the a. femoralis (af), then it reaches to the medial and comes to the medial of the femur behind a. femoralis and v. femoralis. It extends below in the depth of $\mathrm{m}$. adductor longus and ends by divaricating at the distal $1 / 4$ of the femur (Arinci \& Elhan, 1997; Williams et al., 1989; Federative Committe of Anatomical Terminology, 1998)). Apf and its branches are sufficient to feed the lower extremities in the by-pass procedures utilized in the treatment of lower extremity circulation disorders in the clinic (Linder, 1989). Lack of apf is clinically important regarding the ischemia of the lower extremity (Colborn et al., 1995). Comprehensive knowledge of apf and its branches, which has lots of anastomosis and variations, is crucial in vascular surgery and angiography applications (Ekinci et al., 1993).

The fact that the number of cases regarding the lack of apf is very low in the literature constitutes the reason of our research in this subject.

\section{MATERIAL AND METHOD}

In this study, angiography films from the archives of the Medical Faculty of Cumhuriyet University were used. 1036 lower extremities were examined in the remaining 644 angiography films. 893 of them were in men while the remaining 143 were in women. Cases without apfs wereexamined in the films and their rate of occurrence was determined.

\section{RESULTS}

Four out of 1036 lower extremities examined in 644 angiography films did not have apf $(0.4 \%)$. All of these cases occurred in men and they were asymmetrical. The cases were as follows:

Case 1: Lack of apf was found in the right lower extremity of a 32 year old male. Apf and its branches were normal in the left lower extremity (Fig. 1).

Vocational School of Health Services, Cumhuriyet Üniversity, Sivas, Turkey

** Department of Anatomy, Cumhuriyet Üniversity, Faculty of Medicine, Sivas, Turkey

**** Department of Radiology, Cumhuriyet Üniversity, Faculty of Medicine, Sivas, Turkey

***** Physicial Education and Sport High School, Cumhuriyet Üniversity, Sivas, Turkey

****** Kongre High School, Sivas, Turkey 
Case 2: Lack of apf was found in the right lower extremity of a 37 year old male. Apf and its branches were normal in the left lower extremity (Fig. 2).

Case 3: Lack of apf was found in the left lower extremity of a 47 year old male. Apf was present in the right extremity, and a. circumflexa femoris lateralis (acfl) originated from this artery while a. circumflexa femoris medialis (acfm) originated from a. femoralis (Fig. 3).

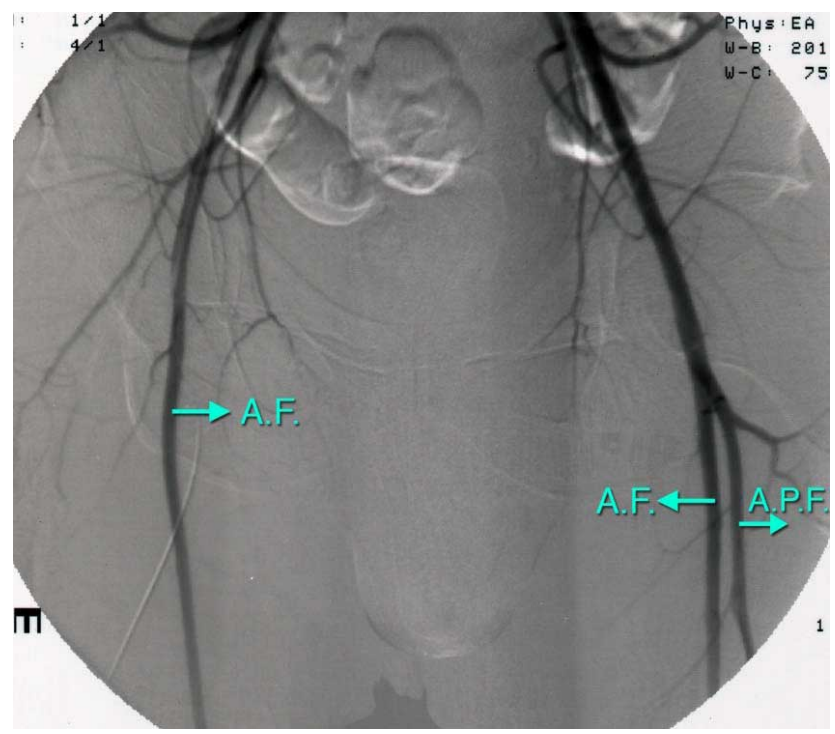

Fig. 1. Lack of apf was found in the right lower extremity of a 32 year old male.

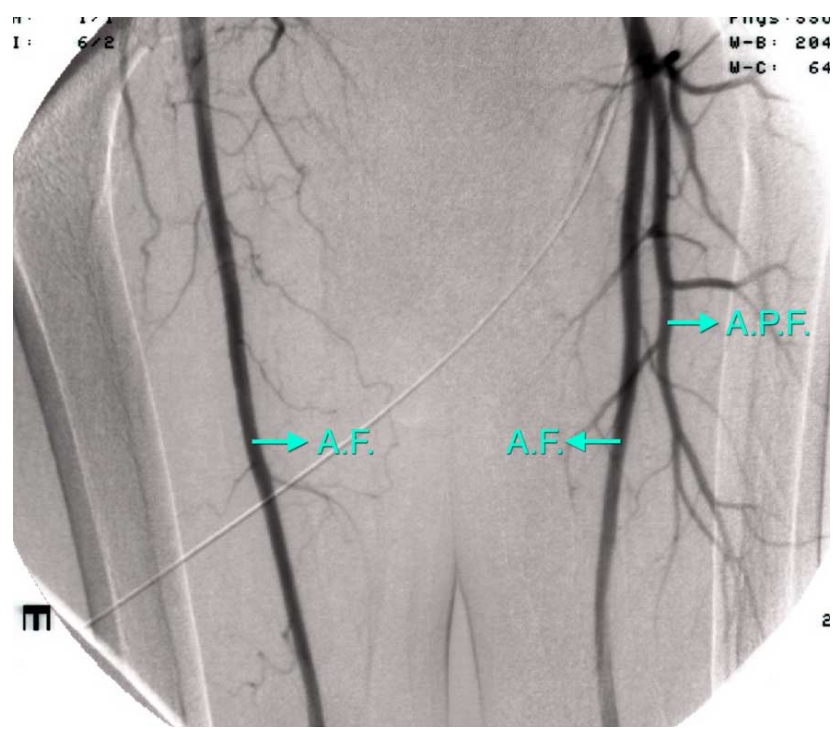

Fig. 2. Lack of apf was found in the right lower extremity of a 37 year old male.

Case 4: Lack of apf was found in the left lower extremity of a 53 year old male. There was clogging in a. iliaca externa in the right lower extremity while there was no a. femoralis or its branches, and it was found that collateral veins have developed (Fig. 4).

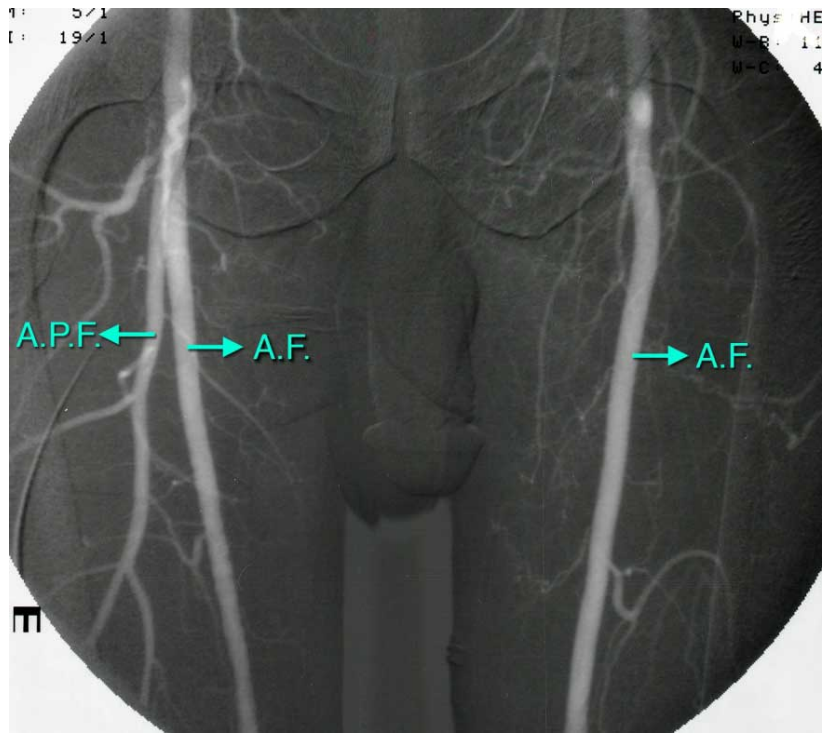

Fig. 3. Lack of apf was found in the left lower extremity of a 47 year old male.

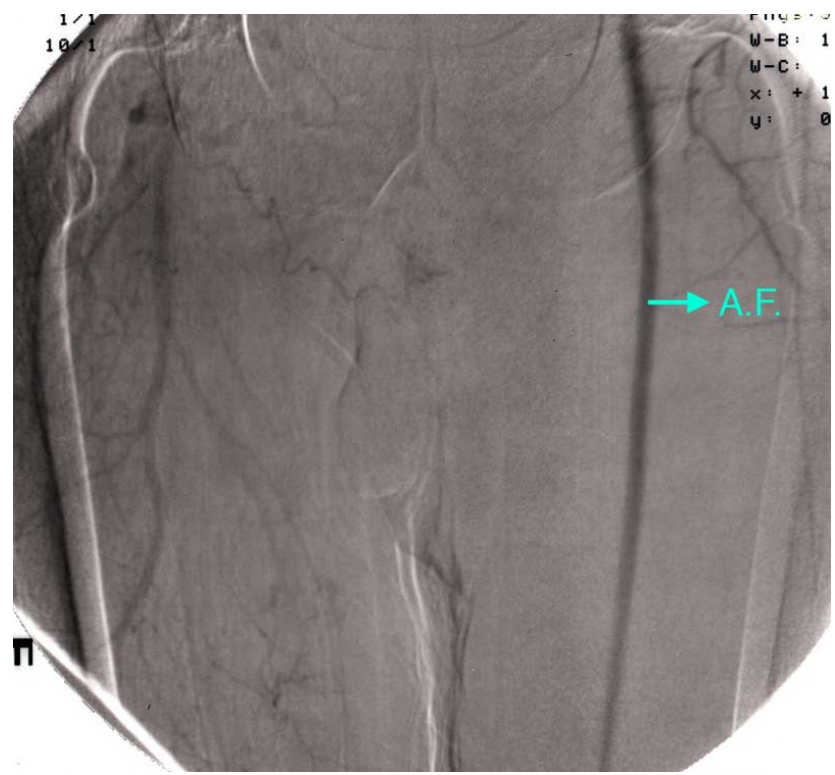

Fig. 4. Lack of apf was found in the left lower extremity of a 53 year old male.

\section{DISCUSSION}

Artery variations are the main variation cases that have importance in clinical and surgical practices besides knowledge of classical anatomy. Lack of apf is a rare variation among them (Lipshutz, 1916; Anger et al., 1984). 
In the absence of such vein, the area it normally feeds gets fed by the surface branches of a. femoralis (Sahin \& Bilgiç, 1998).

We have seen apf absence in 4 of 1036 lower extremities examined in this study $(0.4 \%)$. Poirier assumes that each variation is symmetrical (Poirier, 1912). Huber (1941) found 65\% symmetry in the main branching groups of all the arteries in the body while Massoud \& Flecher (1997) found 79\% symmetry in the original variations of the branches of a. femoralis. Variations were asymmetrical in our cases. Among the models lacking apf in our study, two of them were in the right lower extremity while the other two were in the left lower extremity. They concurred with the studies that emphasize that it is not important whether it is right or left in the variations of the lower extremity arteries (Basar et al., 2002; Williams et al., 1934; De Beer, 1965). While some researchers stated that gender doesn't play a role in the original variations of the lower extremity arteries (Massoud \& Fletcher; Williams et al., 1934), some on the other hand emphasized that it is important (Basar et al.; Suder \& Nizankowski, 1985). Also in our study, all the cases without apf occurred in men.

Surgical action on femoris in the arteria prof. is frequently necessary in the reconstructive procedure of the vein. Also, the muscular branches of femoris in the a. prof attracts considerable attention for myocutaneus procedure in plastic surgery (Cormack \& Lamberty, 1985; Deiler et al., 2000). Additionally, a. profunda femoris is the entry point of diagnostic angiographic procedure (Meschan, 1975; Baum $\&$ Pentecost, 2006). Such examples show the clinical and surgical importance of the knowledge of variations in the a. profunda femoris.

\section{ACKNOWLEDGEMENTS.}

Thank Cumhuriyet University Medical School Department of Radiology.

OTAG, I.; ÇIMEN, M.; SOLAK, O.; OTAG, A.; ÇIMEN, F. G. \& KOSAR, M. I. Ausencia de la arteria femoral profunda. Int. J. Morphol., 30(2):428-431, 2012.

RESUMEN: La arteria femoral profunda, se origina de la arteria femoral, siendo la rama principal que alimenta al muslo. Después de la evolución embriológica de las aa. iliofemorales, muchas variaciones pueden verse en este vaso. La ausencia de una a. femoral profunda es una rara variación observada dentro de estas variaciones. Conocer la anatomía y las variaciones de la a. femoral profunda, es importante para la isquemia de los miembros inferiores, cirugía vascular y aplicaciones en angiografía. En este estudio, fueron examinadas retrospectivamente 1036 placas imagenológicas del miembro inferior, pertenecientes al departamento de Radiología de la Facultad de Medicina de la Cumhuriyet University. Entre estas placas, en cuatro casos pertenecientes a hombres, se detectó la ausencia de la a. femoral profunda. Los casos comprendieron a individuos cuyas edades eran 32, 37, 47 y 53 años, respectivamente. En el primer y segundo caso en el miembro inferior derecho no había una a. femoral profunda y en el miembro inferior izquierdo, se vio que la aa. circunflejas femorales medial y lateral se originaban de la a. femoral profunda. En el tercer caso se observó ausencia de la a. femoral profunda en el miembro inferior izquierdo, y en el miembro inferior derecho, la a. circunfleja femorale lateral se originaba desde la a. femoral profunda, y la a. circunfleja femoral medial se originaba desde la a. femoral. En el cuarto caso en el miembro inferior izquierdo, no existía la a. femoral profunda y en el miembro inferior derecho se observó que tanto la a. femoral como la a. femoral profunda tenían un curso variable. La ausencia de la a. femoral profunda fue del $0,4 \%$. Los resultados fueron analizados y comparados con la literatura.

PALABRAS CLAVE: Arteria femoral profunda; Arteria femoral; Variación; Angiografía.

\section{REFERENCES}

Anger, P.; Seidel, K.; Kauffmann, G. \& Urbanyi, B. Unusual variations of the large arteries of the thigh. Rofo, 141(3):31826, 1984.

Arinci, K. \& Elhan, A. Anatomi. 2. Baski. Ankara, Günes Kitapevi, 1997.

Basar, R.; Sargon, M. F.; Cumhur, M.; Bayramoglu, A. \& Demiryürek, D. Distinct intergender difference in the femoral artery ramification patterns found in the Turkish population: angiographic study. Anat. Sci. Int., 77(4):250-3, 2002.
Baum, S. \& Pentecost, M. J. Abrams Angiography: Interventional Radiology. 2nd ed. Philadelphia, Lippincott Williams \& Wilkins, 2006.

Colborn, G. L.; Mattar, S. G.; Taylor, B.; Skandalakis, J. E. \& Lumsden, A. B. The surgical anatomy of the deep femoral artery. Am. Surg., 61(4):336-46, 1995.

Cormack, G. C. \& Lamberty, B. G. The blood supply of thigh skin. Plast. Reconstr. Surg., 75(3):342-54, 1985. 
De Beer, P. M. The profunda femoris and circumflex femoral arteries in the South African Bantu-speaking Negro. S. Afr. J. Med. Sci., 30(1):1-10, 1965.

Deiler, S.; Pfadenhauer, A.; Widmann, J.; Stützle, H.; Kanz, K. G. \& Stock, W. Tensor fasciae latae perforator flap for reconstruction of composite Achilles tendon defects with skin and vascularized fascia. Plast. Reconstr. Surg., 106(2):342-9, 2000 .

Ekinci, N.; Unur, E. \& Ülger, H. Arteria Femoralis ile Arteria Profunda Femoris ve Dallarının Varyasyonları. Erciyes Tip Dergisi, 15(4):396-9, 1993.

Federative Committe of Anatomical Terminology (FCAT). Terminologia anatomica. Stuttgart, Thieme, 1998.

Huber, J. F. The arterial network supplying the dorsum of the foot. Anat. Rec., 80:373-91, 1941.

Linder, H. H. A Large Medical Book Clinical Anatomy. Prentice Hall International Inc. Appletion Lange, New York, 1989.

Lipshutz, B. B. Studies on the vascular tree. I. A composite study of the femoral artery. Anat. Rec., 10:361-70, 1916.

Massoud, T. F. \& Fletcher, E. W. Anatomical variants of the profunda femoris artery: an angiographic study. Surg. Radiol. Anat., 19(2):99-103, 1997.

Meschan, I. The pelvis and lower extremity. In: An atlas of anatomy basic to radiology. Philadelphia, W.B. Saunders Co., 1975. pp.167-71.

Poirier, P. Traité d'Anatomie Humaine. Paris, Battaille, 1912. p.734. Vol 2.

Sahin, B. \& Bilgiç, S. Two rare arterial variations of the deep femoral artery in the newborn. Surg. Radiol. Anat., 20(3):2335,1998 .

Suder, E. \& Nizankowski, C. Variations in the origin of the deep femoral arteries in human fetuses. Folia Morphol., 44(3-4):2629, 1985.

Williams, G. D.; Martin, C. H. \& McIntire, L. R. Origin of the deep and circumflex femoral group of arteries. Anat. Rec., 60:189-96, 1934.

Williams, P. L.; Warwick, R.; Dyson, M. \& Bannister, L. H. Gray's Anatomy. 37th edition. London, Churchill Livingstone, 1989.

\author{
Correspondence to: \\ Dr. Aynur Otag \\ Physicial Education and Sport High School \\ Cumhuriyet Üniversity, Sivas \\ TURKEY \\ Email: otagaynur@gmail.com
}

Received: 12-08-2011

Accepted: 06-03-2012 